\title{
The CD-Ioop of PAI-2 (SERPINB2) is redundant in the targeting, inhibition and clearance of cell surface uPA activity Blake J Cochran ${ }^{1}$, Lakshitha P Gunawardhana1,2, Kara L Vine ${ }^{1}$, Jodi A Lee ${ }^{1}$, Sergei Lobov ${ }^{1}$ and Marie Ranson*1
}

Address: ${ }^{1}$ School of Biological Sciences, University of Wollongong, NSW, 2522, Australia and ${ }^{2}$ Current address: Department of Respiratory and Sleep Medicine, Hunter Medical Research Institute, John Hunter Hospital, Newcastle, NSW, 2310, Australia

Email: Blake J Cochran - blake@uow.edu.au; Lakshitha P Gunawardhana - lapg@gmail.com; Kara L Vine - kara@uow.edu.au; Jodi A Lee - jal31@uow.edu.au; Sergei Lobov - sergei@uow.edu.au; Marie Ranson* - mranson@uow.edu.au

* Corresponding author

Published: I4 May 2009

BMC Biotechnology 2009, 9:43 doi:10.1 186/1472-6750-9-43
Received: 29 December 2008

Accepted: 14 May 2009

This article is available from: http://www.biomedcentral.com//472-6750/9/43

(C) 2009 Cochran et al; licensee BioMed Central Ltd.

This is an Open Access article distributed under the terms of the Creative Commons Attribution License (http://creativecommons.org/licenses/by/2.0), which permits unrestricted use, distribution, and reproduction in any medium, provided the original work is properly cited.

\begin{abstract}
Background: Plasminogen activator inhibitor type-2 (PAI-2, SERPINB2) is an irreversible, specific inhibitor of the urokinase plasminogen activator (uPA). Since overexpression of uPA at the surface of cancer cells is linked to malignancy, targeting of uPA by exogenous recombinant PAI-2 has been proposed as the basis of potential cancer therapies. To this end, reproducible yields of high purity protein that maintains this targeting ability is required. Herein we validate the use in vitro of recombinant $6 \times$ His-tagged-PAI-2 lacking the intrahelical loop between $\mathrm{C}$ and $\mathrm{D}$ alpha-helices (PAI$2 \triangle \mathrm{CD}$-loop) for these purposes.
\end{abstract}

Results: We show that PAI-2 $\triangle \mathrm{CD}$-loop expressed and purified from the PQE9 vector system presents an easier purification target than the previously used pETI5b system. Additionally, PAI-2 $\triangle C D$-loop gave both higher yield and purity than wild-type PAI-2 expressed and purified under identical conditions. Importantly, absence of the CD-loop had no impact on the inhibition of both solution phase and cell surface UPA or on the clearance of receptor bound UPA from the cell surface. Furthermore, uPA:PAI-2 $\triangle$ CD-loop complexes had similar binding kinetics $\left(K_{D} \sim 5 \mathrm{nM}\right)$ with the endocytosis receptor Very Low Density Lipoprotein Receptor (VLDLR) to that previously published for uPA:PAI-2 complexes.

Conclusion: We demonstrate that the CD-loop is redundant for the purposes of cellular uPA inhibition and cell surface clearance (endocytosis) and is thus suitable for the development of antiuPA targeted cancer therapeutics.

\section{Background}

Plasminogen activator inhibitor type-2 (PAI-2) is a clade $B$ serine protease inhibitor (SERPIN) that is found as both a $60 \mathrm{kDa}$ glycoprotein and a non-glycosylated $47 \mathrm{kDa}$ form [1]. Both forms efficiently inhibit soluble or receptor-bound urokinase plasminogen activator (uPA) $[1,2]$ by the classical serpin inhibitory mechanism resulting in irreversible inhibition of the enzyme [3]. The majority of expressed PAI-2 is not secreted and this may be linked to an inefficient, mildly hydrophobic internal signal peptide $[4,5]$. Thus, whilst PAI-2 levels in plasma are normally too low to be detected, in conditions such as pregnancy, some myelomonocytic leukemias and in inflammatory tissue, PAI-2 is consistently detected in plasma and other body 


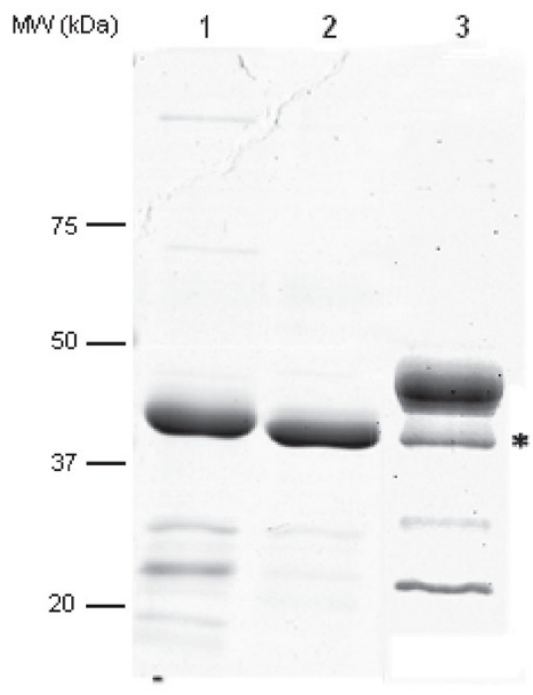

\section{Figure I}

SDS-PAGE analysis of highly enriched recombinant PAl-2 proteins. $10 \mu \mathrm{g}$ of total protein from PAI-2 $\Delta$ CDloop purified from either $\mathrm{PETI} 5 \mathrm{~b}$ (lane I) or PQE9 (lane 2), or wild-type PAI-2 from PQE9 (lane 3) were fractionated by a $10 \%$ SDS-PAGE under reducing conditions. The slight difference in size between PAI-2 $\triangle$ CD-loop from pETI5b and PQE9 is due to differences in tag/linker length. * marks cleaved PAI-2 in wild-type population as mentioned in text. fluids as both a glycoprotein and in the $47 \mathrm{kDa}$ form [59]. This suggests a role for PAI-2 in extracellular protease inhibition in vivo.

We have previously shown that exogenous PAI-2 efficiently inhibits cell surface UPA receptor (UPAR)-bound uPA leading to the rapid clearance of the inhibited complex from the cell surface via receptor mediated endocytosis [2]. This involves interactions with endocytosis receptors of the Low Density Lipoprotein receptor (LDLR) family leading to delivery of uPAR/uPA/PAI-2 to endosomes and lysosomes $[2,10,11]$. Tumour overexpression of $\mathrm{uPA} / \mathrm{UPAR}$ and the related uPA inhibitor PAI-1 (SERPINE1) strongly correlates to metastatic potential [12-16] and poor patient prognosis [17-20], but the presence of PAI-2 is associated with benign tumours and increased, relapse-free survival [9]. As such, we proposed that the ability of PAI-2 to remove cell surface uPA and hence proteolytic activity, without activation of the promitogenic/motogenic signalling pathways associated with PAI-1 $[9,11]$, accounts for the differential prognosis seen for PAI-2 versus PAI-1 [9-11].

Therefore, the ability of PAI-2 to specifically target uPA and hence tumour cells without interacting with components of the ECM or modifying other cellular behaviours that may promote tumour cell behaviour (unlike PAI-1) [11], supports the use of exogenous PAI-2 as the basis of uPA targeted cancer treatments. Promising results using

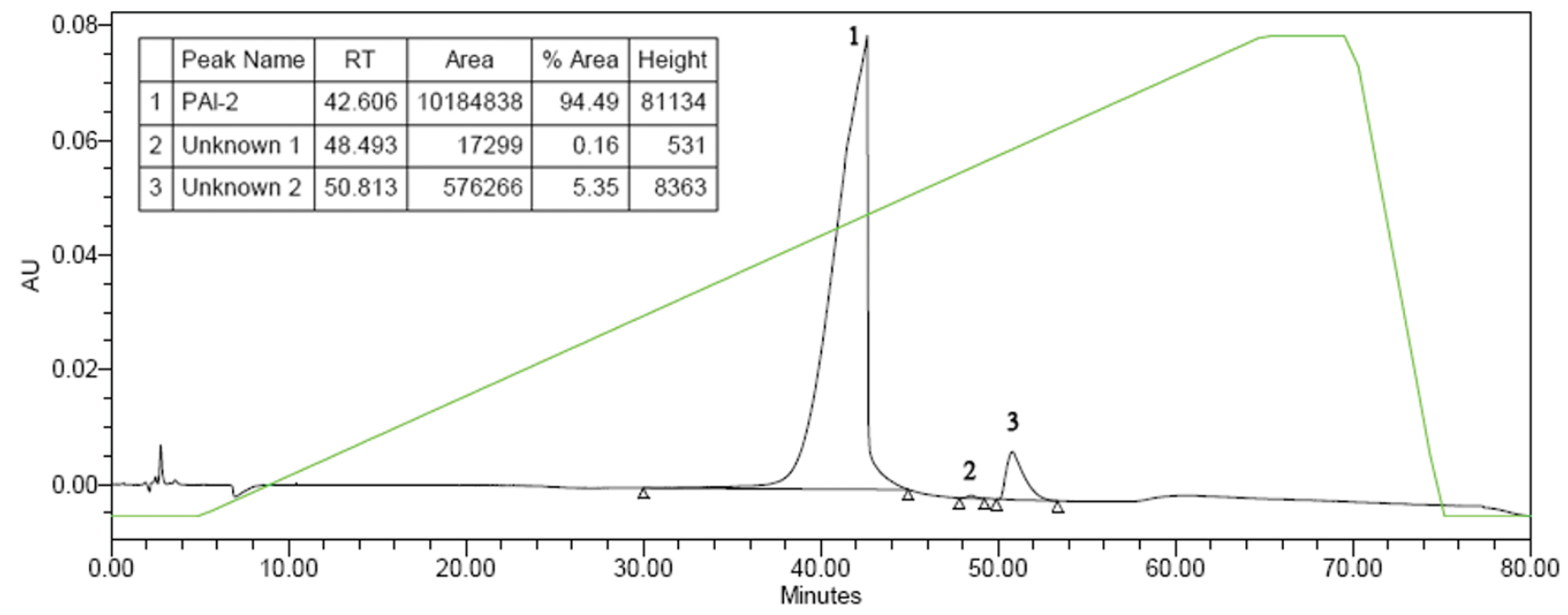

Figure 2

Quantitative analysis of the purification of PAI-2 $\Delta$ CD-loop from pQE9. Protein (I00 $\mu \mathrm{L})$ was injected onto a cation exchange column and eluted using a linear $\mathrm{NaCl}$ gradient $(0-I \mathrm{M})$ at I $\mathrm{mL} / \mathrm{min}$. PAI-2 $\Delta \mathrm{CD}$-loop was detected at $280 \mathrm{~nm}$ with a RT of $42.606 \mathrm{~min}$. Integration of the peak corresponding to PAI-2 $\triangle \mathrm{CD}$-loop measured the purity at $94.5 \%$. The green line

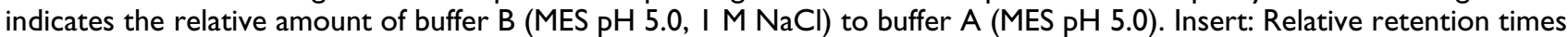
hatand purity as calculated from AUC using Empower Pro V2 (Waters) software. RT = retention time. 


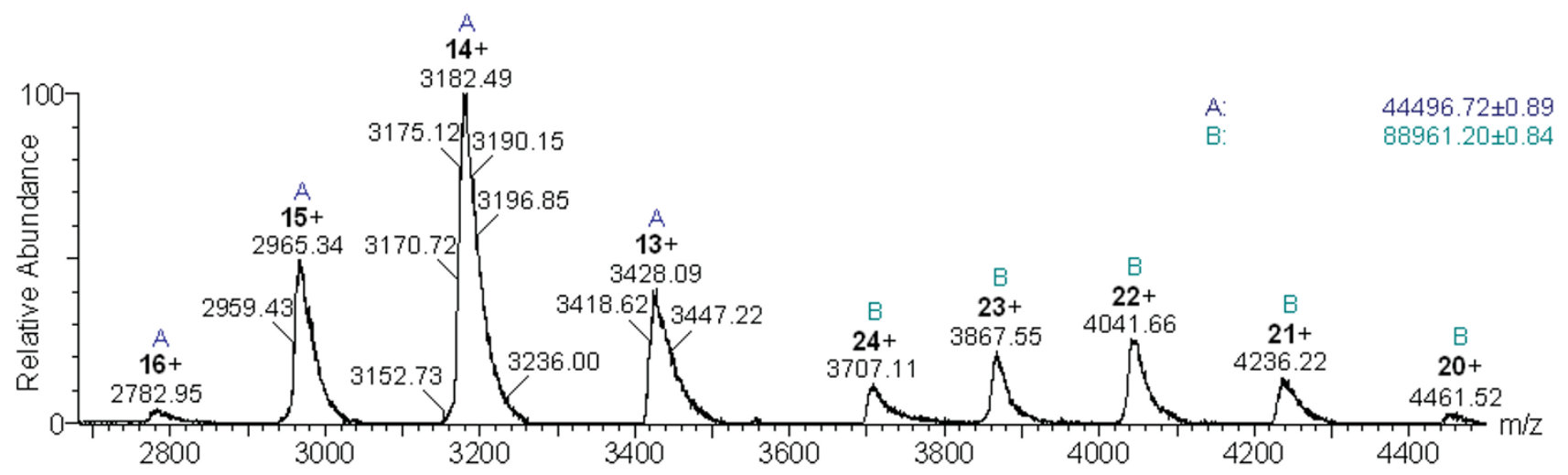

\section{Figure 3}

A positive ion ESI-MS of PAI-2 $\triangle$ CD-loop from pQE9 in $10 \mathrm{mM}$ ammonium acetate (pH 6.8) containing $0.1 \%$ formic acid. The $\mathrm{m} / \mathrm{z}$ spectrum shows a Gaussian-type distribution of multiply charged ions ranging from $\mathrm{m} / \mathrm{z} 2700-4500$. Charge states are indicated. The monomeric $(\mathbf{A})$ and dimeric $(\mathbf{B})$ forms of the protein gave a measured molecular mass of $44496 \mathrm{Da}( \pm 0.89)$ and $8896 \mathrm{I} \mathrm{Da}( \pm 0.84)$, respectively. Mass was calculated using MassLynx MS software (Waters) and caesium iodide was used for external calibration.

bismuth-213 labelled PAI-2 have been obtained in a number of in vitro, in vivo and preclinical evaluations which show clear cell targeting specificity and tumour efficacy with minimal side effects in relevant animal models [21-27]. These studies used full length wild-type PAI-2, but it may be possible to utilise smaller, more easily producible PAI- 2 constructs. This would require validation in terms of its extracellular uPA inhibitory and clearance functions.

Previous studies have reported the purification of PAI-2 from placenta [28], cultured human monocytes [29], transfected CHO cells [30,31], baculovirus infected insect larvae [32], yeast [33] and Escherichia coli [30,34-43]. Methods of PAI-2 expression in E. coli have generally utilised a one or two step purification procedure, usually involving metal affinity chromatography and/or ion exchange chromatography. The shift in the literature towards affinity tag based systems for the production of recombinant PAI-2 constructs [34-39] allows for the purification of PAI-2 under milder, native conditions and avoidance of denaturation/renaturation [35] or extreme $\mathrm{pH}$ treatment [30] as used previously. The presence of an $N$-terminal $6 \times$ His-tag has previously been shown to have no significant impact on the uPA inhibitory activity of PAI-2 [36]. Generally, His-tags are believed to have no effect on overall protein structure [44].

An issue associated with the purification of recombinant wild-type PAI-2 is that PAI-2 contains a 33 amino acid intrahelical loop between alpha helices $\mathrm{C}$ and $\mathrm{D}$ (known as the CD-loop) which is accessible for cleavage in both $E$. coli or mammalian expression systems [34]. This results in two fractions of recombinant PAI-2 which retain inhibitory activity but require additional purification steps such as ion-exchange chromatography [34]. Di Giusto et al. [38] showed that $6 \times$ His-tagged PAI-2 lacking the CDloop (termed PAI-2 $\Delta$ CD-loop) can be purified with a one-step procedure and exhibited identical soluble phase uPA inhibitory activity.

The functionality of the CD-loop has been described primarily in an intracellular context and remains somewhat controversial [9]. The CD-loop is involved in transglutaminase mediated cross-linking to cellular and ECM proteins $[43,45]$, although the functional significance of this crosslinking is unknown. Interestingly, cross-linked PAI-2 maintains uPA inhibitory activity. The CD-loop is believed to be highly mobile [34] and as such the crystal structure of PAI-2 has only been resolved for a CD-loop deletion mutant [42].

Altogether, this suggests that PAI-2 $\Delta$ CD-loop, being easy to produce and purify in addition to retaining uPA inhibitory activity, could be used as an exogenous uPA targeting substitute for wild-type PAI-2 in a therapeutic setting. To this end, we compared the expression and purification of $6 \times$ His-tagged wild type PAI- 2 and PAI- $2 \Delta$ CD-loop and show for the first time that the cell bound uPA inhibitory activity and rapid clearance of $\mathrm{uPAR} / \mathrm{uPA}$ by PAI- 2 is not compromised by the $6 \times$ His-tagged form lacking the CDloop. 

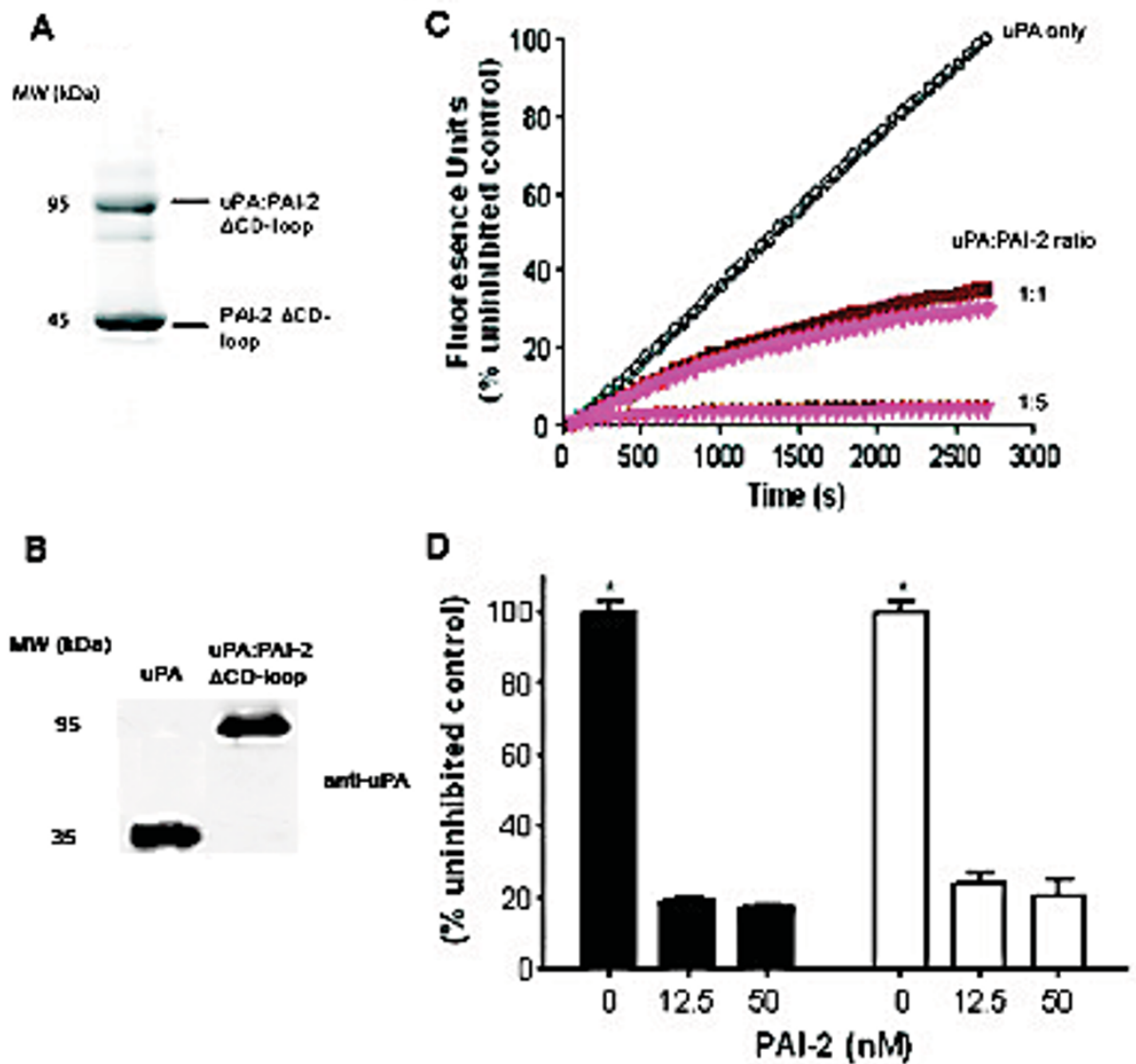

\section{Figure 4}

PAI-2 $\triangle$ CD-loop efficiently inhibits both solution phase and cell bound uPA activity. A. PAI-2 $\triangle$ CD-loop is able to form SDS stable complexes with uPA. PAI-2 $\triangle$ CD-loop was incubated in a 2:I molar ratio with HMW-uPA for 30 min and analysed by a $10 \%$ SDS-PAGE under reducing conditions. B. Immunoblot analysis of complex formation between uPA and PAI-2 $\triangle C D$-loop using a monoclonal antibody to the A-chain of uPA $(\sim 30 \mathrm{kDa})$, indicating that no residual uPA remains in the sample. C. Kinetic inhibition curves for wild-type PAI-2 (dark red) versus PAI-2 $\triangle$ CD-loop (bright pink) against HMW-uPA in solution. The uPA fluorogenic substrate was briefly pre-incubated with the PAI-2 forms or buffer alone (open circles) and the assays initiated by the addition of HMW-uPA. Fluorescence units were converted to a percentage of the maximal (uninhibited) uPA activity. Values shown are the means of triplicate determinations. Errors (<10\%) are not shown for clarity of presentation. D. U937 cells were incubated with uPA fluorogenic substrate in the absence or presence of wild-type PAI-2 (filled bars) or PAI-2 $\triangle \mathrm{CD}$-loop (open bars) for $\mathrm{I} \mathrm{h}$ at $37^{\circ} \mathrm{C}$. Fluorescence units were converted to a percentage of the maximal (uninhibited) uPA activity. Values shown are means $\pm \operatorname{SEM}(n=3)$. ${ }^{*} p<0.00$ I compared to inhibited samples for both PAI- 2 forms.

\section{Results and discussion \\ Expression and purification of PAI-2 $\triangle$ CD-loop}

Expression and purification of PAI-2 $\triangle \mathrm{CD}$-loop from both the pET15b and pQE9 vector systems yielded a product migrating as a major band at $45 \mathrm{kDa}$ (Figure 1). This corresponds to the expected molecular weight of PAI-2 $\Delta \mathrm{CD}$ loop and was confirmed via western blotting with a monoclonal antibody to PAI-2 (data not shown). The PAI-2 $\triangle \mathrm{CD}$-loop from the $\mathrm{pQE} 9$ system contained fewer impurities (seen as lower molecular weight bands; Figure 1) compared to PAI-2 $\triangle$ CD-loop from pET15b expressed and purified under similar conditions (Figure 1, compare lanes 1 and 2). The abundance of PAI-2 $\Delta \mathrm{CD}$-loop expressed and purified from the pQE9 versus the pET15b system was found to be $~ 95 \%$ pure compared to $74 \%$, respectively, as measured by densitometry. The purity of PAI-2 $\triangle$ CD-loop was confirmed via HPLC, with integration of the elution profile giving PAI-2 $\Delta$ CD-loop an abundance of $~ 95 \%$ (Figure 2). The expression and purification of PAI-2 $\triangle \mathrm{CD}$-loop using the PQE9 system regularly achieved yields between 10 and $15 \mathrm{mg} / \mathrm{L}$ of culture. Wild-type PAI-2 expressed and purified using the pQE9 system was less pure (Figure 1, compare lanes 1 and 3) and of lower yield ( $\sim 5 \mathrm{mg} / \mathrm{L})$ compared to PAI- $2 \Delta \mathrm{CD}$ - 
Table I: Kinetic parameters of the interaction between PAI-2 $\triangle$ CD-loop or wild-type PAI-2 and VLDLR, both alone and in complex with uPA.

\begin{tabular}{|c|c|c|c|c|c|}
\hline Analyte & Binding Model & $\begin{array}{c}k_{a} \\
\left(M^{-1} s^{-1}\right)\end{array}$ & $\begin{array}{l}k_{d} \\
\left(s^{-1}\right)\end{array}$ & $\begin{array}{c}K_{D} \\
(n M)\end{array}$ & $\chi^{2}$ \\
\hline PAI-2 wild-type & No binding & - & - & - & - \\
\hline uPA:PAI-2 wild-type & $\mathrm{I}: \mathrm{I}$ & $\begin{array}{c}3.75 \times 10^{5} \\
\left( \pm 1.1 \times 10^{5}\right)\end{array}$ & $\begin{array}{c}1.44 \times 10^{-3} \\
\left( \pm 0.39 \times 10^{-3}\right)\end{array}$ & $\begin{array}{c}4.81 \\
( \pm 0.64)\end{array}$ & 4.71 \\
\hline PAI-2 $\Delta$ CD-loop & No binding & - & - & - & - \\
\hline uPA:PAI-2 $\Delta$ CD-loop & I:I & $\begin{array}{c}4.16 \times 10^{5} \\
\left( \pm 1.8 \times 10^{5}\right)\end{array}$ & $\begin{array}{c}1.36 \times 10^{-3} \\
\left( \pm 0.23 \times 10^{-3}\right)\end{array}$ & $\begin{array}{c}4.34 \\
( \pm 0.56)\end{array}$ & 3.28 \\
\hline
\end{tabular}

Values were determined using surface plasmon resonance. Binding data was fitted using the BIAevaluation 4.0 software. The binding model chosen represents that with the lowest $\chi^{2}$ value. (Values are the average $\pm S E M, n=3$ ).

loop. When visualised by SDS-PAGE under reducing conditions, wild-type PAI-2 yielded two bands that were identified as PAI-2 via western blotting (data not shown). This confirms our previous observation that a portion of wildtype PAI-2 is cleaved in the CD-loop [34], which would require further purification steps to obtain a homogenous protein population.

\section{Electrospray lonisation Mass Spectrometry (ESI-MS)}

The mass spectrometry data presented here is the first spectrum of any PAI-2 construct to be published. The ESIMS spectrum of PAI-2 $\Delta$ CD-loop (Figure 3 ) shows a pattern of multiply charged ions $\left(13^{+}\right.$to $\left.16^{+}\right)$in the $\mathrm{m} / z$ range

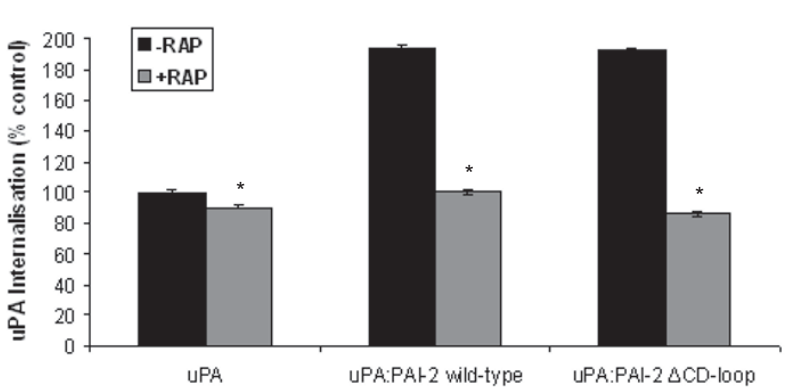

\section{Figure 5}

Cellular internalisation of uPA is equivalent between wild-type PAI-2 and PAI-2 $\triangle$ CD-loop as determined by flow cytometry. MCF-7 cells were incubated with 10 nM uPA:Alexa ${ }_{488}$, either alone or in complex with wild-type PAI- 2 or PAI- $\triangle \triangle \mathrm{CD}$-loop for I $\mathrm{h}$ at $37^{\circ} \mathrm{C}$. Any surface bound uPA:Alexa ${ }_{488}$ remaining was quenched by incubation with 4 $\mu \mathrm{g} / \mathrm{mL}$ anti-Alexa ${ }_{488}$ polyclonal antibody for $30 \mathrm{~min}$ prior to analysis by dual colour flow cytometry. Values shown are means \pm SEM $(n=3)$ as a percentage of uPA only treatment.* $p<0.005$ compared to internalisation in the absence of RAP for each treatment. of 2700-3500 consistent for the $45 \mathrm{kDa}$ monomeric species. The calculated molecular weight of $44496.72 \mathrm{Da}$ is in agreement with the theoretical monoisotopic molecular weight of $44480.16 \mathrm{Da}$. In addition, five higher charge states $\left(20^{+}\right.$to $\left.24^{+}\right)$from $\mathrm{m} / z 3,700-4,500$ representing an $89 \mathrm{kDa}$ dimeric species were also observed. Lobov et al. [34] showed that whilst less polymergenic than wild-type PAI-2, PAI-2 $\Delta$ CD-loop was still able to form dimers and higher order aggregates.

\section{The absence of the CD-loop does not affect the solution phase or cell surface uPA activity inhibitory function of PAI-2}

To ensure that the PAI-2 $\Delta \mathrm{CD}$-loop construct generated in this study retained uPA inhibitory activity, excess PAI-2 $\triangle$ CD-loop was incubated with uPA and analysed by SDSPAGE under reducing conditions (Figure 4A). A band at $\sim 95 \mathrm{kDa}$ was observed corresponding to covalently complexed uPA:PAI-2 $\triangle$ CD-loop. Additionally, western blotting of this complex formation using a monoclonal antibody to uPA showed no free uPA remained after incubation (Figure 4B). PAI-2 $\Delta$ CD-loop and wild-type PAI-2 gave super-imposable kinetic inhibition curves for HMW$\mathrm{uPA}$ in solution (Figure 4C), confirming that the absence of the CD-loop does not affect uPA inhibitory activity of PAI-2. Di Giusto et al. [38] showed that His-tagged PAI-2 $\triangle \mathrm{CD}$-loop had the same second order rate constant (2.40 $\left.\times 10^{6} \mathrm{M}^{-1} \mathrm{~s}^{-1}\right)$ as the published wild-type non-recombinant form. Moreover, we show that the inhibitory activity of both variants was also identical towards cell surface receptor bound UPA as there were no significant differences seen between the two PAI-2 forms (Figure 4D). This indicates that the absence of the CD-loop is also redundant in the more physiological setting of the cell surface. This is to be expected as the majority of serpin sequence deviation occurs in the loops joining secondary structures [46]. Moreover, the intrahelical CD-loop is a unique feature of clade B serpins [47] which is absent (and hence not 
required for function) in inhibitory serpins of all other clades.

\section{Removal of the CD-loop does not affect the clearance of uPA from the cell surface}

Preliminary dot-blot analysis suggested that removal of the CD-loop of PAI-2 has no impact on the interaction between uPA complexed PAI-2 and members of the LDLR family [10]. Surface plasmon resonance was used to measure the affinity of uPA complexed with PAI-2 $\Delta$ CD-loop or wild-type PAI-2 for the endocytosis receptor VLDLR. The $\mathrm{K}_{\mathrm{D}}$ of both uPA:PAI-2 $\Delta \mathrm{CD}$-loop and uPA:wild-type PAI-2 for VLDLR was found to be $\sim 5 \mathrm{nM}$ (Table 1) and these interaction best fit a 1:1 binding model. Additionally, no interaction was observed between VLDLR and either PAI$2 \Delta$ CD-loop or wild-type PAI-2 alone (Table 1). These findings are in agreement with those of Croucher et al. [11], which was determined using non-tagged, wild-type PAI-2. Additionally, when complexed with uPA, both wild-type PAI-2 and PAI-2 $\Delta$ CD-loop lead to an almost two-fold increase in the amount of uPA endocytosed by MCF-7 cells relative those treated with uPA alone (Figure 5). Importantly, there was no significant difference between cells treated with uPA:wild-type PAI-2 and uPA:PAI-2 $\triangle$ CD-loop. Pre-treatment of cells with the LDLR antagonist RAP significantly reduced the amount of uPA internalised in all treatments (Figure 5). This also confirms the role of VLDLR in endocytosis, as it is the only LDLR family member of relevance on MCF-7 cells [11].

\section{Conclusion}

This study shows that the CD-loop of PAI-2 plays no role in the inhibition and clearance of cell surface uPA in vitro. Additionally, we confirm previous findings indicating that the use of PAI- $\Delta$ CD-loop is advantageous compared to wild-type PAI-2 due to superior purity and yield of the recombinant protein under identical conditions. As such, PAI-2 $\Delta$ CD-loop appears to present a desirable basis for the development of PAI-2 based uPA targeted cancer therapies. Furthermore, tumour uptake increases as protein size is decreased [48], suggesting that this shortened but fully active form of PAI-2 may not only be simpler to express and purify than wild-type PAI-2, but also exhibit a favourable pharmacokinetic profile.

\section{Methods \\ Materials}

The expression vectors pET15b/PAI-2 wild-type and pET15b/PAI-2 $\Delta$ CD-loop were a kind gift from Prof. T Ny (Umea University, Sweden); pQE9 vector and M15 [pREP4] E. coli obtained from QIAgen; Oligonucleotides from Sigma-Genosys; phorbyl myristate acetate (PMA) from Sigma-Aldrich; Alexa ${ }_{488}$ labelling kit, Alexa ${ }_{488}$ polyclonal antibody and BL21 Star (DE3) E. coli from Invitrogen; IPTG from Applichem; Monoclonal antibodies against human uPA (\#394) and human PAI-2 (\#3750), and high molecular weight (HMW)-uPA from American Diagnostica; Ampicillin and kanamycin from Amresco; TALON metal affinity resin from Clontech; BamHI restriction enzyme, shrimp alkaline phosphatase and T4 DNA ligase from Fermentas; CM5 BIAcore chip and PD-10 desalting columns from GE BioSciences; Recombinant VLDLR ligand binding region was a gift from D Blaas (Medical University of Vienna, Austria); Z-Gly-Gly-ArgAMC from Calbiochem; Wild-type PAI-2 from PAI-2 Pty Ltd; Pfu HS Fusion II DNA polymerase from Stratagene.

\section{Generation of PQE9/PAI-2 constructs}

Wild-type PAI-2 and PAI-2 $\triangle$ CD-loop cDNAs lacking the 3 ' untranslated region were amplified from pET15b using Pfu HS Fusion II DNA polymerase and the following primers: 5'-GCGCGGATCCCTCGAGGATCTTTGTGTGGC-3' (forward) and 5'-GCGCGGATCCTTAGGGTGAGGAAAATCTGCCG-3' (reverse). Primers contained BamHI sites to allow for ligation into pQE9. Both vector and insert were digested with BamHI, linear pQE9 de-phosphorylated using shrimp alkaline phosphatase and the insert ligated into the vector using T4 DNA ligase. Successful insertion and sequence integrity were confirmed using restriction digestion and DNA sequencing.

\section{Expression and purification of PAI-2}

Purified pET15b/PAI-2 $\Delta$ CD-loop, pQE9/PAI-2 $\Delta$ CD-loop and PQE9/PAI-2 wild-type vectors were transformed into chemically competent BL21 Star (DE3) and M15 [pREP4] cells, respectively, using standard methods. Cells were cultured overnight at $37^{\circ} \mathrm{C}$ with shaking in LB containing $100 \mu \mathrm{g} / \mathrm{mL}$ ampicillin and $25 \mu \mathrm{g} / \mathrm{mL}$ kanamycin (only for M15 [pREP4] cells). A $20 \mathrm{~mL}$ aliquot of this starter culture was added to $1 \mathrm{~L}$ Z-broth (LB with the addition of $1 \mathrm{~g} / \mathrm{L}$ glucose and $0.49 \mathrm{~g} / \mathrm{L} \mathrm{CaCl} 2 \cdot 2 \mathrm{H}_{2} \mathrm{O}$ ) and grown to an $\mathrm{OD}_{600}$ of $\sim 0.6$. Expression of PAI-2 $\triangle$ CD-loop was induced by the addition of $0.5 \mathrm{mM}$ IPTG and the culture incubated for a further $4 \mathrm{~h}$. Cells were collected by centrifugation at $10,000 \mathrm{~g}$ for $10 \mathrm{~min}$. Pelleted cells were resuspended in $15 \mathrm{~mL}$ of ice-cold loading buffer $(50 \mathrm{mM}$ $\mathrm{NaH}_{2} \mathrm{PO}_{4}, 300 \mathrm{mM} \mathrm{NaCl}, \mathrm{pH} 7.0$, containing $5 \mathrm{mM}$ imidazole for pET15b expressed PAI-2 $\Delta$ CD-loop) and lysed using a French press (Thermo, USA). The cell lysate ( 20 $\mathrm{mL}$ ) was then incubated with $2.5 \mu \mathrm{g}$ of DNase for $30 \mathrm{~min}$ on ice and cell debris pelleted by centrifugation at 17,000 $g$ for $30 \mathrm{~min}$. The supernatant was loaded onto equilibrated TALON metal affinity resin at a rate of $1 \mathrm{~mL} / \mathrm{min}$. Unbound proteins were removed using 10 column volumes of loading buffer followed by 10 column volumes of wash buffer containing optimised imidazole concentrations (data not shown) (50 mM NaH${ }_{2} \mathrm{PO}_{4}, 300 \mathrm{mM} \mathrm{NaCl}$, $5 \mathrm{mM}$ imidazole for pQE9, $15 \mathrm{mM}$ for pET15b, pH 7.0). Bound protein was eluted from the column using elution buffer $\left(50 \mathrm{mM} \mathrm{NaH}{ }_{2} \mathrm{PO}_{4}, 300 \mathrm{mM} \mathrm{NaCl}, 150 \mathrm{mM}\right.$ imida- 
zole, pH 7.0). Purification was analysed using SDS-PAGE under reducing conditions and the successful isolation of PAI-2 $\Delta$ CD-loop determined by western blotting using a monoclonal antibody against PAI-2. Samples were buffer exchanged into phosphate buffer $\left(50 \mathrm{mM} \mathrm{NaH} \mathrm{PO}_{4}, 300\right.$ $\mathrm{mM} \mathrm{NaCl}, \mathrm{pH} 7.0$ ) to remove imidazole for subsequent experiments.

\section{Cation-exchange high performance liquid chromatography (HPLC)}

The purity of PAI-2 $\Delta$ CD-loop expressed and purified from $\mathrm{PQE} 9$ was further determined by ion exchange chromatography on a BioSuite SP $10 \mu \mathrm{m}, \mathrm{C} \times \mathrm{C}(7.5 \mathrm{~cm} \times 75$ $\mathrm{mm}$ ) cation exchange semi-preperative column (Waters, UK). The column was pre-equilibrated with approximately 10 column volumes of $20 \mathrm{mM}$ 2-(N-morpholino)ethanesulfonic acid (MES, pH 5.0). PAI-2 $\triangle \mathrm{CD}-$ loop $(100 \mu \mathrm{L}, \sim 1 \mathrm{mg} / \mathrm{mL})$ was then loaded and eluted with a linear (curve 6) $0.5 \mathrm{M} \mathrm{NaCl}$ salt gradient at $1 \mathrm{~mL} /$ min. The data was collected on a photodiode array (PDA) at $280 \mathrm{~nm}$ and percent purity determined using Empower Pro V2 (Waters, UK) software.

\section{Electrospray ionisation mass spectrometry (ESI-MS)}

A positive ion mass spectrum of PAI-2 $\Delta$ CD-loop expressed and purified from pQE9 was acquired on a quadrupole time of flight spectrometer (Q-TOF-MS) (Micromass Q-TOF Ultima, Waters, UK) fitted with a Zspray ionisation source. A sample of freshly prepared protein in PBS pH 7.4 was exchanged into $10 \mathrm{mM}$ ammonium acetate buffer ( $\mathrm{pH} 6.8$ ) containing $0.1 \%$ formic acid and made up to a final concentration of $10 \mu \mathrm{M}$. The protein was then injected into the Q-TOF Ultima mass spectrometer $(20 \mu \mathrm{L})$ and the mass spectrum acquired with a capillary voltage of $2.6 \mathrm{kV}$, cone voltage of $50 \mathrm{~V}$, source block temperature of $40^{\circ} \mathrm{C}$, and a resolution power of $5000 \mathrm{~Hz}$. Ceasium iodide was used for external calibration. The mass spectrum data is presented as raw data, on an $m / z$ scale. Mass was calculated using MassLynx MS software (Waters).

\section{Fluorogenic uPA activity assay}

Several substrate and uPA concentrations were used to find the optimum range and to set the gain on a Fluorostar Optima fluorescence plate reader (BMG Labtech, Germany). PAI-2 $\triangle$ CD-loop or wild-type PAI-2 were diluted in reaction buffer $(20 \mathrm{mM}$ Hepes, pH 7.6, $100 \mathrm{mM} \mathrm{NaCl}$, $0.5 \mathrm{mM}$ EDTA, $0.01 \%(\mathrm{v} / \mathrm{v})$ Tween 20$)$ and mixed with fluorogenic substrate, Z-Gly-Gly-Arg-AMC in $180 \mu \mathrm{L}$ reaction buffer. After a brief preincubation at $37^{\circ} \mathrm{C}, \mathrm{HMW}$ $\mathrm{uPA}$ (final concentration $0.675 \mathrm{nM}$ ) was added to start the reaction and fluorescence emission measured immediately at $37^{\circ} \mathrm{C}$. All assays were performed in triplicate and values corrected by subtracting the background (reaction buffer plus substrate only). For cell based assays, PMA treated U937 cells (used to enhance the expression of unoccupied UPAR [49]) were washed and preincubated with $50 \mathrm{nM}$ HMW-uPA in binding buffer (Phenol red free Hanks buffered salt solution, $\mathrm{pH} 7.4$, containing $1 \mathrm{mM}$ $\mathrm{CaCl}_{2}, 1 \mathrm{mM} \mathrm{MgCl}_{2}$ and $0.1 \% \mathrm{BSA}$ ) for $10 \mathrm{~min}$ to saturate uPAR. After 2 washes the cells were resuspended in binding buffer to give a final concentration of $5 \times 10^{5}$ cells $/ \mathrm{mL}$. To initiate the reaction $100 \mu \mathrm{L}$ aliquots of the cell suspension were transferred to a 96-well fluor plate containing $100 \mu \mathrm{L}$ of $0.5 \mathrm{mM}$ substrate $+/$ - PAI- 2 in binding buffer pre-equilibrated to $37^{\circ} \mathrm{C}$ (final concentrations, $0.25 \mathrm{mM}$ substrate, 12.5 or $50 \mathrm{nM}$ PAI-2) and fluorescence emission measured. All assays were performed in triplicate and values corrected by subtracting background fluorescence [binding buffer plus substrate +/- PAI-2 (the presence of PAI-2 made no difference to background levels)]. Differences in uPA activity were tested for significance using an unpaired Student's t-test.

\section{Surface plasmon resonance}

Surface plasmon resonance was used to determine the impact of the removal of the CD-loop and presence of the $6 \times$ His-tag on the affinity of uPA:PAI- 2 complexes for VLDLR, essentially as described by Croucher et al. [11]. VLDLR was immobilised on a CM5 BIAcore chip, according to the manufacture's instructions. Briefly, the chip was activated with a 1:1 mixture of $0.2 \mathrm{M} N$-ethyl-N'-(3dimethylaminopropyl)carbodi-imide and $0.05 \mathrm{M} N$ hydroxysuccimide. VLDLR was coated onto the chip at 40 $\mu \mathrm{g} / \mathrm{mL}$ in $10 \mathrm{mM}$ sodium acetate $(\mathrm{pH} 3)$ to a level of $\sim 2,000$ response units. Unoccupied binding sites were blocked using $1 \mathrm{M}$ ethanolamine, $\mathrm{pH}$ 8.5. Ligands were diluted into running buffer $(10 \mathrm{mM}$ Hepes, $\mathrm{pH} 7.4,150$ $\mathrm{mM} \mathrm{NaCl}, 1 \mathrm{mM} \mathrm{CaCl}_{2}, 0.005 \%$ Tween-20) before application to the BIAcore chip at $20 \mu \mathrm{L} / \mathrm{min}$. Regeneration was achieved using $100 \mathrm{mM} \mathrm{H}_{3} \mathrm{PO}_{4}$. Data was analysed using BIAevaluation software (Version 4), using a blank cell as the reference cell.

\section{Internalisation assays}

Internalisation assays were conducted essentially as previously described $[2,10,11]$, using the MCF-7 cell line. Briefly, cells were grown for $48 \mathrm{~h}$ in 6 well plates to subconfluency, washed with phenol red free hanks buffered salt solution ( $\mathrm{pH} 7.4$, containing $1 \mathrm{mM} \mathrm{CaCl}_{2}, 1 \mathrm{mM}$ $\mathrm{MgCl}_{2}$ and $0.1 \% \mathrm{BSA}$ ), then incubated in binding buffer for $1 \mathrm{~h}$ at $37^{\circ} \mathrm{C}$ to allow for receptor recycling. To confirm LDLR specificity, cells were preincubated for $10 \mathrm{~min}$ with $200 \mathrm{nM}$ RAP (receptor associated protein). Cells were incubated with $10 \mathrm{nM}$ uPA:Alexa ${ }_{488}$, both alone and previously complexed with either wild-type PAI-2 or PAI-2 $\Delta \mathrm{CD}$-loop for $1 \mathrm{~h}$ at $37^{\circ} \mathrm{C}$ to allow for internalisation. After this incubation period, the cells were washed twice with ice cold binding buffer, harvested using $5 \mathrm{mM}$ EDTA, washed again and resuspended in ice cold binding buffer 
containing $4 \mu \mathrm{g} / \mathrm{mL}$ Alexa $_{488}$ quenching polyclonal antibody. After 30 min the cells were washed twice with icecold PBS and analysed by dual colour flow cytometry with propidium iodide to exclude non-viable cells as previously described [2]. Differences in the amount of uPA internalised between treatments were tested for significance using the unpaired Student's t-test.

\section{Abbreviations}

AUC: Area under the curve; ECM: Extracellular matrix; HMW: High molecular weight; HPLC: High performance liquid chromatography; LDLR: Low density lipoprotein receptor; PAI-2: Plasminogen activator inhibitor type-2; PAI-1: Plasminogen activator inhibitor type-1; PMA: Phorbyl myristate acetate; RAP: Receptor associated protein; RT: Retention time; uPA: Urokinase plasminogen activator; uPAR: Urokinase plasminogen activator receptor; VLDLR: Very low density lipoprotein receptor.

\section{Authors' contributions}

$\mathrm{BC}$ compiled and wrote the manuscript, carried out experiments and assisted in planning of the study. LG built the constructs used in this study and carried out initial experimental work. KV conducted experiments, contributed data and wrote sections of the manuscript. JL provided and analysed experimental data. SL was involved in the planning and supervision of the project and writing sections of the manuscript. MR was involved in the planning, funding and supervision of the study, writing of the manuscript and generating experimental data. All authors read and approved the final manuscript.

\section{Acknowledgements}

$\mathrm{BC}$ and JL are recipients of Australian Postgraduate Awards.

MR is a Cancer Institute NSW Fellow.

\section{References}

I. Kruithof EKO, Baker MS, Bunn CL: Biological and clinical aspects of plasminogen activator inhibitor type 2. Blood 1995, 86:4007-4024

2. Al-Ejeh F, Croucher D, Ranson M: Kinetic analysis of plasminogen activation inhibitor type-2: urokinase complex formation and subsequent internalisation by carcinoma cell lines. Experimental Cell Research 2004, 297:259-27I.

3. Gettins PGW: Serpin structure, mechanism, and function. Chemical Reviews 2002, 102:475I-4803.

4. Belin D, Wohlwend A, Schleuning WD, Kruithof EKO, Vassalli JD: Facultative polypeptide translocation allows a single mRNA to encode the secreted and cytosolic forms of plasminogen activators inhibitor 2. EMBO Journal 1989, 8:3287-3294.

5. von Heijne G, Liljeström P, Mikus P, Andersson H, Ny T: The efficiency of the uncleaved secretion signal in the plasminogen activator inhibitor type 2 protein can be enhanced by point mutations that increased its hydrophobicity. Journal of Biological Chemistry 1991, 266:15240-15243.

6. Kawano T, Morimoto K, Uemura Y: Partial purification and properties of urokinase inhibitor from human placenta. Journal of Biological Chemistry (Tokyo) 1970, 67:333-342.

7. Brenner B: Haemostatic changes in pregnancy. Thrombosis Research 2004, I I4:409-4I4.

8. Astedt B, Lecander I, Ny T: The placental type of plasminogen activator inhibitor, PAI-2. Fibrinolysis 1987, 1:203-208.
9. Croucher DR, Saunders DN, Lobov S, Ranson M: Revisiting the biological roles of PAI2 (SERPINB2) in cancer. Nature Reviews Cancer 2008, 8:535-545.

10. Croucher D, Saunders DN, Ranson M: The urokinase/PAI-2 complex: a new high affinity ligand for the endocytosis receptor low density lipoprotein receptor-related protein. J Biol Chem 2006, 281: 10206-10213.

II. Croucher DR, Saunders DN, Stillfried GE, Ranson M: Structural basis of differential signaling by PAI-I and PAI-2 in breast cancer: Implications for metastatic potential. Biochemical Journal 2007, 408:203-210.

12. Scherrer A, Wohlwend A, Kruithof EKO, Vassalli JD, Sappino AP: Plasminogen activation in human acute leukaemias. British Journal of Haematology 1999, 105:920-927.

13. Duffy MJ, Maguire TM, McDermott EW, O'Higgins N: Urokinase plasminogen activator: A prognostic marker in multiple types of cancer. Journal of Surgical Oncology 1999, 71:130-135.

14. Look MP, van Putten WLJ, Duffy MJ, Harbeck N, Christensen IJ, Thomssen C, Kates R, Spyratos F, Fernö M, Eppenberger-Castori S, et al:: Pooled analysis of prognostic impact of urokinase-type plasminogen activator and its inhibitor PAI- $I$ in 8377 breast cancer patients. Journal of the National Cancer Institute 2002, 94: $116-128$.

15. Schmitt M, Wilhelm OG, Reuning $U$, Krüger A, Harbeck N, Lengyel $E$, Graeff H, Gänsbacher B, Kessler H, Bürgle M, et al.: The urokinase plasminogen activator system as a novel target for tumour therapy. Fibrinolysis \& Proteolysis 2000, 14: | |4- I32.

16. Weigelt $B$, Peterse JL, van't Veer LJ: Breast cancer metastasis: Markers and Models. Nature Reviews Cancer 2005, 5:591-602.

17. Duffy MJ: The urokinase plasminogen activator system: role in malignancy. Current Pharmaceutical Design 2004, 10:39-49.

18. Foekens JA, Peters HA, Look MP, Portengen H, Schmitt M, Kramer MD, Brunner N, Janicke F, Meijer-van Gelder ME, Henzen-Logmans SC, et al.: The urokinase system of plasminogen activation and prognosis in $\mathbf{2 7 8 0}$ breast cancer patients. Cancer Research 2000, 60:636-643.

19. Ohba K, Miyata Y, Kanda S, Koga S, Hayashi T, Kanetake H: Expression of urokinase-type plasminogen activator, urokinasetype plasminogen activator receptor and plasminogen activator inhibitors in patients with renal cell carcinoma: correlation with tumour associated macrophage and prognosis. Journal of Urology 2005, 174:46I-465.

20. Choong PFM, Nadesapillai APW: Urokinase plasminogen activator system: A multifunction role in tumor progression and metastasis. Cancer Orthopadedics and Related Research 2003, 4I5S:S46-S58.

21. Qu CF, Song EY, Li Y, Rizvi SM, Raja C, Smith R, Morgenstern A, Apostolidis C, Allen B]: Pre-clinical study of ${ }^{213}$ Bi labeled PAI2 for the control of micrometastatic pancreatic cancer. Clinical \& Experimental Metastasis 2005, 22:575-586.

22. Li Y, Rizvi SM, Ranson M, Allen BJ: ${ }^{213}$ Bi-PAI2 conjugate selectively induces apoptosis in PC3 metastatic prostate cancer cell line and shows anti-cancer activity in a xenograft animal model. British Journal of Cancer 2002, 86: I I 97-I 203.

23. Stutchbury TK, Al-Ejeh F, Stillfried GE, Croucher DR, Andrews J, Irving D, Links M, Ranson M: Preclinical evaluation of 213 Bi-labeled plasminogen activator inhibitor type 2 in an orthotopic murine xenogenic model of human breast carcinoma. Molecular Cancer Theraputics 2007, 6:203-2I2.

24. Ranson M, Tian Z, NM A, Rizvi S, Allen BJ: In vitro cytotoxicity of bismuth-2 I3 $(213 \mathrm{Bi})$-labeled-plasminogen activator inhibitor type 2 (alpha-PAI-2) on human breast cancer cells. Breast cancer research and treatment 2002, 7I:I49-I59.

25. Song YJ, Qu CF, Rizvi SM, Li Y, Robertson G, Raja C, Morgenstern A Apostolidis C, Perkins AC, Allen BJ: Cytotoxicity of PAI2, C595 and Herceptin vectors labeled with the alpha-emitting radioisotope Bismuth-213 for ovarian cancer cell monolayers and clusters. Cancer Letters 2006, 234:176-I83.

26. Abbas Rizvi SM, Li Y, Song EY, Qu CF, Raja C, Morgenstern A, Apostolidis C, Allen B]: Preclinical studies of bismuth-2 13 labeled plasminogen activator inhibitor type 2 (PAI2) in a prostate cancer nude mouse xenograft model. Cancer Biology \& Therapy 2006, 5:386-393.

27. Allen BJ, Tian Z, Rizvi SMA, Li Y, Ranson M: Preclinical studies of targeted $\alpha$ therapy for breast cancer using ${ }^{213} \mathrm{Bi}$-labelled- 
plasminogen activator inhibitor type 2. British Journal of Cancer 2003, 88:944-950.

28. Wun TC, Reich E: An inhibitor of plasminogen activation from human placenta. The Journal of Biological Chemistry 1987, 262:3646-3653.

29. Kruithof EK, Vassalli J-D, Schleuning W-D, Mattaliano RJ, Bachman F: Purification and characterization of a plasminogen activator inhibitor from the histiocytic lymphoma cell line U-937. The Journal of Biological Chemistry 1986, 26 I: I I207-I I2 I3.

30. Mikus $\mathrm{P}$, Urano $\mathrm{T}$, Liljestrom $\mathrm{P}, \mathrm{Ny} \mathrm{T}$ : Plasminogen-activator inhibitor type 2 (PAI-2) is a spontaneously polymerising SERPIN. Biochemical characterisation of the recombinant intracellular and extracellular forms. European Journal of Biochemistry 1993, 218:107|-1082.

31. Mikus P, Ny T: Intracellular polymerization of the serpin plasminogen activator inhibitor type 2. The Journal of Biological Chemistry 1996, 27I: 10048-10053.

32. Zhang XW, Sun T, Zhou XF, Zeng XY, Liu X, Gu DX: Expression of human PAI-2 in the baculovirus expression system. Journal of Industrial Microbiology \& Biotechnology 1998, 21:175-I 77.

33. Steven J, Cottingham IR, Berry SJ, Chinery SA, Goodey AR, Courtney $M$, Ballance DJ: Purification and characterisation of plasminogen activator inhibitor 2 produced in Saccharomyces cerevisiae. European Journal of Biochemistry I991, 196:431-438.

34. Lobov S, Wilczynska M, Bergstro F, Johansson LBA, Ny T: Structural bases of the redox-dependent conformational switch in the serpin PAI-2. Journal of Molecular Biology 2004, 344: I 359-I 368.

35. Zhou A, Jiang X, Dou F, Zhu D, Xu X: Renaturation, purification, and characterization of human plasminogen activator inhibitor type 2 (PAI-2) accumulated at high level in Escherichia coli. The Journal of Biochemistry 1997, I 2 1:930-934.

36. Wilczynska M, Lobov S, Ny T: The spontaneous polymerization of plasminogen activator inhibitor type-2 and Z-antitrypsin are due to different molecular aberrations. FEBS Letters 2003 537: II- 16 .

37. Wilczynska M, Lobov S, Ohlsson P-I, Ny T: A redox-sensitive loop regulates plasminogen activator inhibitor type 2 (PAI-2) polymerization. The EMBO Journal 2003, 22: 1753-176I.

38. Di Giusto DA, Sutherland APR, Jankova L, Harrop SJ, Curmi PMG King GC: Plasminogen activator inhibitor-2 is highly tolerant to $\mathbf{P 8}$ residue substitution-Implications for serpin mechanistic model and prediction of nsSNP activities. Journal of Molecular Biology 2005, 353:1069-1080.

39. Muehlenweg B, Guthaus E, Arroyo De Prada N, Schmitt M, Schmiedeberg N, Kotzsch M, Creutzburg S, Kramer MD, Kessler H, Wilhelm $O G$, et al.: Epitope mapping of monoclonal antibodies directed to PAI-I using PAI-I/PAI-2 chimera and PAI-Iderived synthetic peptides. Thrombosis Research 2000, 98:73-8I.

40. Ye RD, Wun T-C, Sadler JE: cDNA cloning and expression in Escherichia coli of a plasminogen activator inhibitor from human placenta. The Journal of Biological Chemistry 1987, 262:37|8-3752.

41. Antalis TM, Clark MA, Barenes T, Lehrbach PR, Devine PL, Schevzov G, Goss NH, Stephens RW, Tolstoshev P: Cloning and expression of a cDNA coding for a human monocyte-derived plasminogen activator inhibitor. Proccedings of the National Academy of Sciences USA 1988, 85:985-989.

42. Jankova L, Harrop SJ, Saunders DN, Andrews JL, Bertram KC, Gould AR, Baker MS, Curmi PM: Crystal structure of the complex of plasminogen activator inhibitor $\mathbf{2}$ with a peptide mimicking the reactive center loop. The Journal of Biological Chemistry 2001, 276:43374-43382

43. Jensen PH, Schuler E, Woodrow GC, Richardson M, Goss NH, Hojrup $P$, Petersen TE, Ranmussen LK: A unique interhelical insertion in plasminogen activator inhibitor-2 contains three glutamines, Gln83, GIn84, GIn86, essential for transglutaminase-mediated cross-linking. Journal of Biological Chemistry 1994, 269:15394-15398.

44. Carson M, Johnson DH, McDonald H, Brouillette C, DeLucas LJ: Histag impact on structure. Acta Crystallographica Section D 2007 , 63:295-301.

45. Jensen PH, Jensen TG, Laug WE, Hager H, Gliemann J, Pepinsky B: The exon 3 encoded sequence of the intracellular serine proteinase inhibitor plasminogen activator inhibitor 2 is a protein binding domain. Journal of Biological Chemistry 1996, 27 1:26892-26899.
46. Irving JA, Pike RN, Lesk AM, Whisstock JC: Phylogeny of the serpin superfamily: implications of patterns of amino acid conservation for structure and function. Genome Research 2000 , 10:1845-1864.

47. Silverman GA, Whisstock JC, Askew DJ, Pak SC, Luke CJ, Cataltepe S, Irving JA, Bird PI: Human clade B serpins (ov-serpins) belong to a cohort of evolutionarily dispersed intracellular proteinase inhibitor clades that protect cells from promiscuous proteolysis. Cellular and Molecular Life Sciences 2004, 61:30I-325.

48. Thomas GD, Chappell MJ, Dykes PW, Ramsden DB, Godfrey KR, Ellis JRM, Bradwell AR: Effect of dose, molecular size, affinity, and protein binding on tumor uptake of antibody or ligand: A biomathematical model. Cancer research 1989, 49:3290-3296.

49. Picone R, Kajtaniak LS, Nielsen LS, Behrendt N, Mastronicola MR, Cubellis MV, Stoppelli MP, Pedersen S, Dano K, Blasi F: Regulation of urokinase receptors in monocytelike U937 cells by phorbol ester myristate acetate. Journal of Cell Biology 1989, 108:693-702.
Publish with Biomed Central and every scientist can read your work free of charge

"BioMed Central will be the most significant development for disseminating the results of biomedical research in our lifetime. "

Sir Paul Nurse, Cancer Research UK

Your research papers will be:

- available free of charge to the entire biomedical community

- peer reviewed and published immediately upon acceptance

- cited in PubMed and archived on PubMed Central

- yours - you keep the copyright
BioMedcentral 